\title{
Determining the Factors Affecting Medical Tourism with Emphasis on Technological Entrepreneurship in Iran
}

\author{
Hamidreza Najjari1 $^{(D)}$, Hossein Didehkhani2 ${ }^{*}$ (D), Mahmoudreza Mostaghimi ${ }^{3}$ (D), \\ Seyyed Mohammadreza Hosseini4 ${ }^{4}$.
}

\begin{abstract}
Introduction: Today, the provision of medical services to international patients around the world has received widespread attention. This opportunity is being applied to increase GDP and raise quality standards for health care services in centers. In Iran, one of the government programs is the expansion of medical tourism. The purpose of the present study is to Design a technological Entrepreneurship-Based medical Tourism Model in Iran.

Methods: The present research is applied-developmental research in terms of its purpose. Due to implementation, it is a Quantitative covered in correlational type .Throughout the first step, to identify the indicators of technological entrepreneurship- based Medical tourism, fuzzy Delphi method was used and in second step, Quantitative -Descriptive-method was applied (Factor-analysis method to practice as well as hierarchical method for grading).

Results: Indicators of Structural Factors with Score 0.382, professional factors with score 0.250, management factors with Score 0.160, Staff Support with Score 0.101, External Factors with Score 0.064, and Inter-Organizational Interaction with Score 0.043 are in the most Priority, respectively.

Conclusion: The results showed that six major indices and 26 sub-indices were introduced as the most significant indices of Entrepreneurship Based Medical Tourism. Applying the mentioned indices is effective in developing and expanding medical tourism industry and can provide supports to the managers and policy makers of the industry.
\end{abstract}

Keywords: Medical Tourism, Fuzzy Delphi, Hierarchical, Technological Entrepreneurship.

•Received: 18/Nov/2019 •Modified: 02/March/2020 •Accepted: 15/March/2020

1. PhD Candidate, Department of Entrepreneurship, Aliabad Katoul Branch, Islamic Azad University ,

Aliabad Katoul, Iran, hamidrezanajjari@yahoo.com

2. Associate Professor, Department of Industries Engineering , Aliabad Katoul Branch ,Islamic Azad University

, Aliabad Katoul, Iran; Corresponding author, h.didehkhani@gmail.com

3. Associate Professor, Department of Management, Aliabad Katoul Branch ,Islamic Azad University, Aliabad

Katoul, Iran, m_r_mostaghimi@yahoo.com

4. Associate Professor, Department of Economy, Aliabad Katoul Branch, Islamic Azad University, Aliabad

Katoul, Iran, mehranhosseini163@gmail.com 


\section{تعيين عوامل مؤثر بر توريسم درمانى با تأكيد بر كار آفرينى فن آورانه

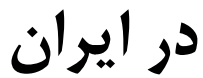

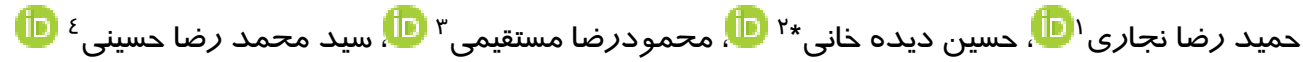

مقدمه: امروزه ارائه خدمات درمانى به بيماران بينالمللى در دنيا بهصورت كسترده از توجه برخوردار است و از اين فرصت، جهت افزايش توليد ناخالص ملى وبالابردن استانداردهاى كيفى ارائه خدمات درمانى استفاده مئمايند. در ايران نيز يكى از برنامههاى دولت، كَترش توريسم درمانى است. هدف يخذوهش حاضر، طراحى الكوى توريسم درمانى مبتنى بر كار آفرينى فن آورانه در ايران است.

روشها: مطالعه حاضر ازلحاظ هدف، كاربردى-توسعه اى از حيث روش اجرا كمى و از نوع همبستكى است. در مرحله اول براي شناسايى شاخصهاى توريسم درمانى مبتنى بر كار آفرينى فن آورانه از روش كمى - دلفى فازى و در مرحله دوم براى برازش از روش كمى-توصيفى (تحليل عاملى و براى رتبهبندى از روش سلسله مراتبى) استفادهشده است.

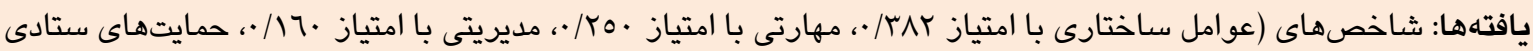

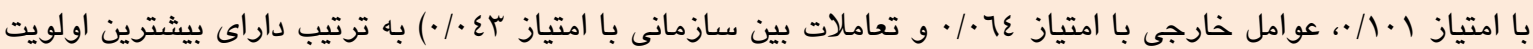
مىباشند. نتيجهكيرى: يافتهایى يذوهش حاضر نشان داد شش شاخص اصلى و بr شاخص فرعى، بهاعنوان مهمترين شاخصهاى توريسم درمانى مبتنى بر كار آفرينى فن آورانه مىباشند كه استفاده از اين شاخصها در رشيد و توسعه هنعت توريسم درمانى

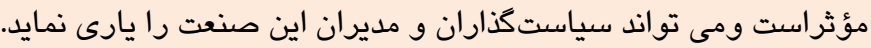

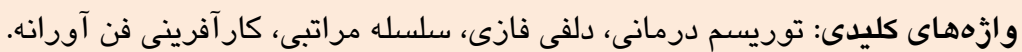

•وصول مقاله:

ا. دانشجوى د كترى ، گروه كار آفرينى، واحد على آباد كتول، دانشگاه آزاد اسلامى، على آباد كتول، ايران،

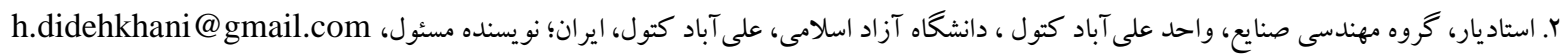

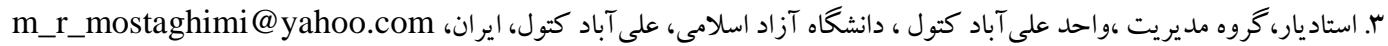

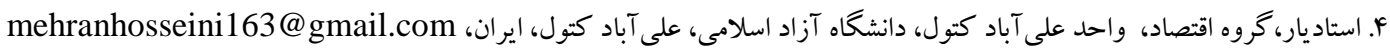


توريسم درمانى، سفرى سازمانيافته از محيط زندگى فرد به

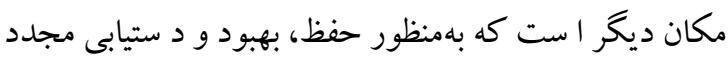

به بلامت جسمى و روحى فرد صورت مى يذيرد.

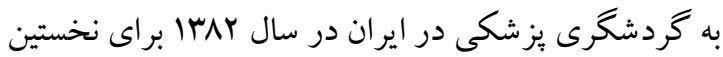
بار از طرف وزارت بهداشت توجه شد. البته وزارت بهداشت

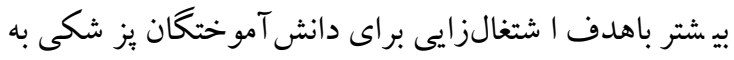
اين مبحث برداخت و نه رونق توريسم درمانى؛ اما كم كم از

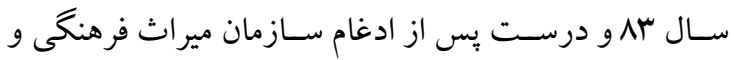

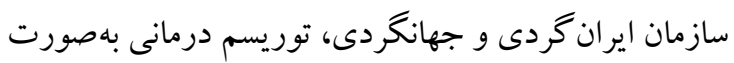

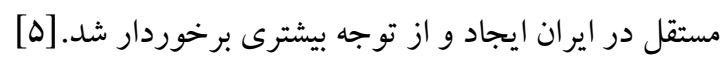

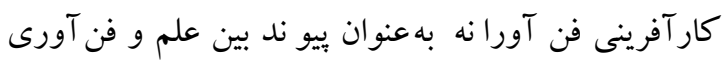

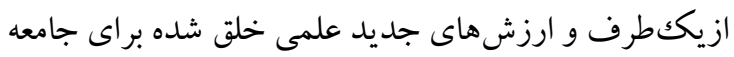

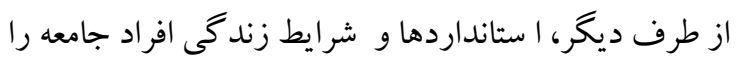
بهبود مىبخشد و در رفاه عمومى، اقتصادى و اجتماعى نقش ايفا مىنمايد. كار آفرينى فن آورانه از دو منظر حائز اهميت

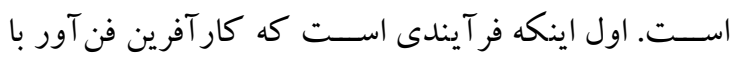

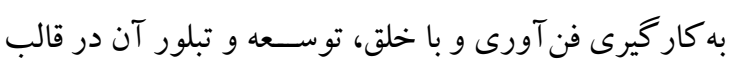

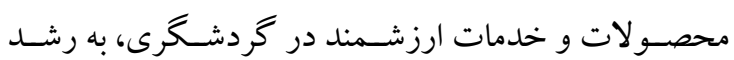

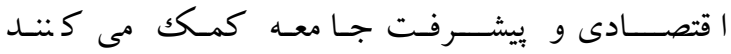

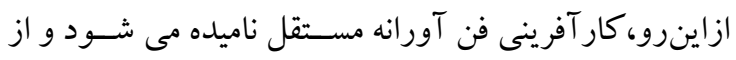

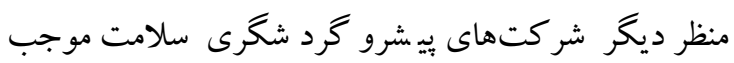

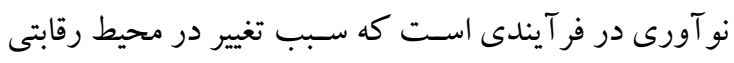
مىشود كه به آن كار آفرينى فن آورانه توريسم درمانى كفته

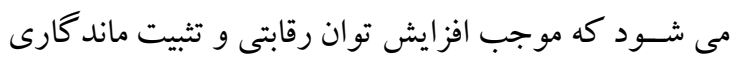

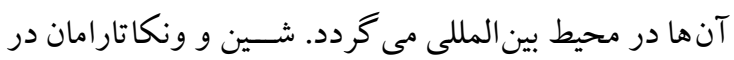
سـال r..r، كار آفرينى فن آورانه را فر آيندهايى در نظر

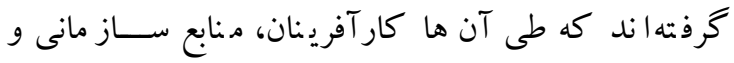
سيستمهاى فنى و راهبر دها را براى د ستيابى به فر صت الها در

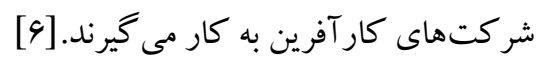
وازههاى معادل متعددى براى كار آفرينى فن آورانه در

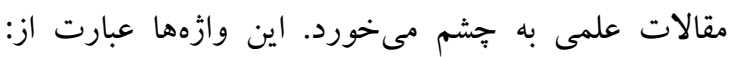
كارآفرينى فن آورانه، كارآفرين فن آورى، كارديه آفرينى

\section{مقدمه - - مق}

ايران ازنظر جاذبههاى گردشــرى طبيعى جزو · ا كثــور

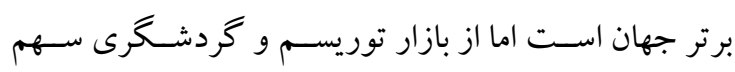

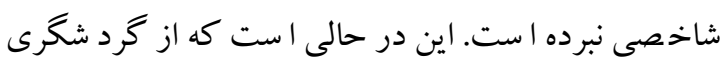

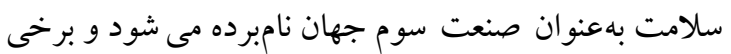

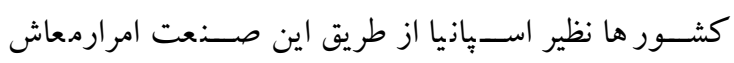

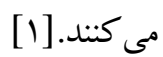
امروزه با صنعتى شدن كشورها و بروز دردهاى مختلف در

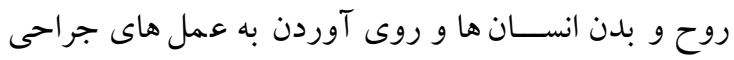

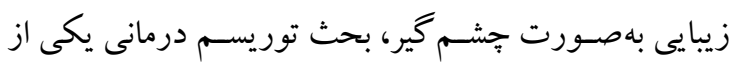

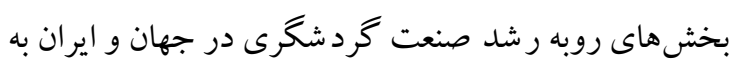
شمار مى آيد. درزمينه توريسم درمانى و جذب روند مرد شكران سلامت همواره بايد به جهار مولفه اساسى در اين زمينه توجه

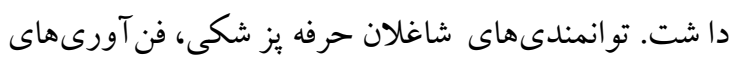
روز و اســتانداردهاى جهانى، اقتصسـاد درمان و هزينه هاى

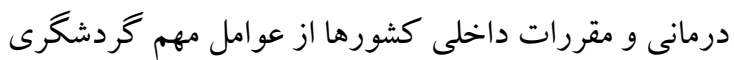

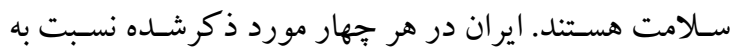
كثــور هاى همســايه و خاورميانه از توانمندى هاى بهترى هرى هرد

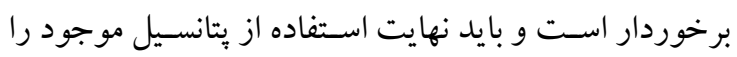

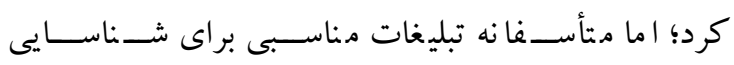

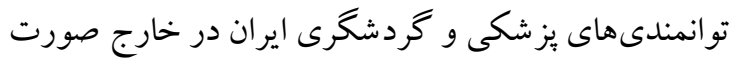
نغخر فته است. رسانه هاى دولتى و سفارت خحانه ها در اين زمينه

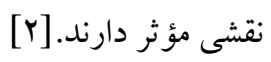
امروزه صنعت توريسم درمانى در جهان بالاتر از صنايع نفت دورنت

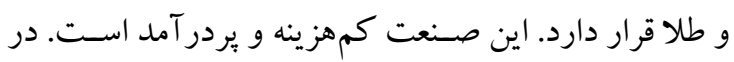

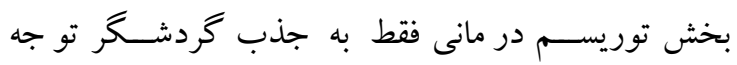
نمى شـــود بلكه فراتر از آن مى تواند موقعيت و جايكاه ايران را ازنظر علمى، سـياسـى، اجتماعى و منطقهاى تقويت كند.

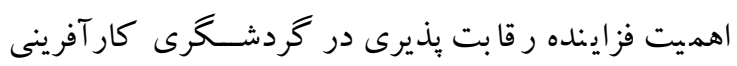

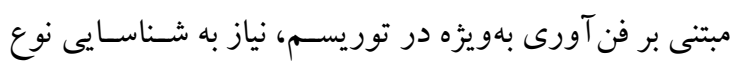

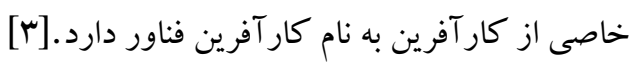


است. ازلحاظ روش گردآورى دادهها يكك مطالعه تو صيفى

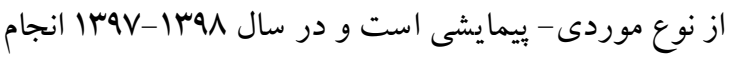

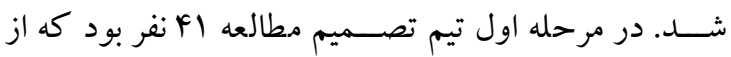
ا ساتيد داز شگاهى و مديران عالى وزارت بهدا شت و درمان كه داراى ويز گى هايى نظير در د سترس بودن، تنا سب ر شته تحصـيلى، مدر كك دكترى يا كارشـناسى ارشــ، اشـتغال به

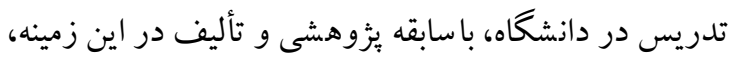
انتخابشــده و در مرحله دوم جامعه آمارى را كارشــاسـان بيمار ستانهاى داراى مجوز يذيرش بيمار بان بين الملل و دفاتر

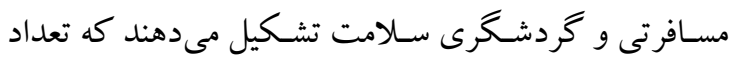

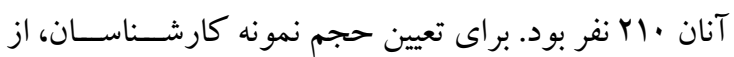

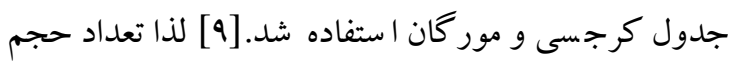

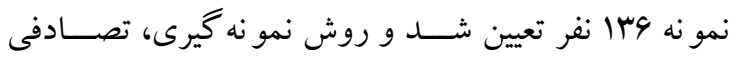

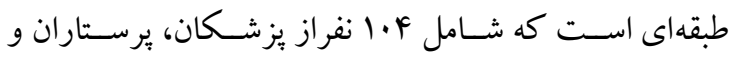
مديران بيمار ستانها و بr نفراز كار شنا سان دفاتر مسافرتى و

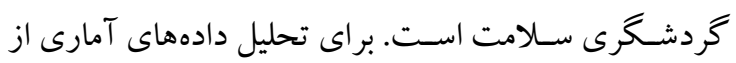

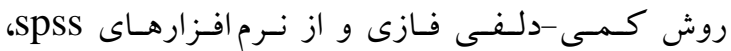
Expert choice،Lisrel با اسـتفاده از روش معادلات ساختارى و سلسله مراتبى و تحليل عاملى و تحليل مـسير و

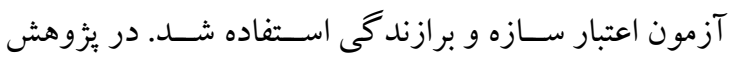

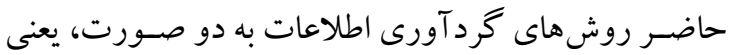
كتابخانهاى و ميدانى بدين صورت كه مباحث نظرى و اصول اوليه طرح از طريق مطالعات كتابخانهاى به دسـت آمد و در ادامه براى ر سيدن به اهداف طرح با ا ستفاده از روش ميدانى و ابزار مصاحبه و برسش نامه، اطلاعات جمع آورى شد. اين يُوهش در دومر حله انجام شد. درمر حله اول ،با توجه به

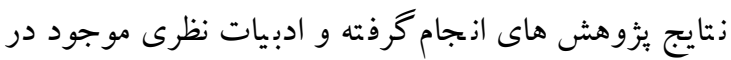
زمينه شنا سايى شاخصهاى كار آفرينى فن آورانه، برخى از شاخصهايى كه به نظر مىر سيد ازجمله شاخص هاى مورد نظر محسـوب شـوند، شــاسـايى و در قالب برسـش نامه در

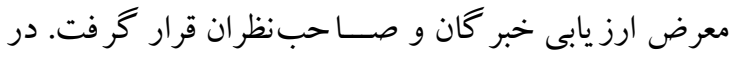

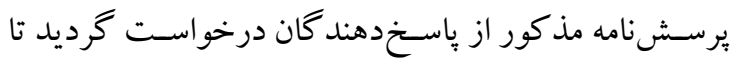

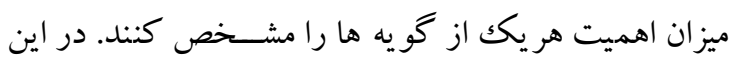

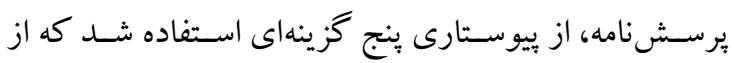

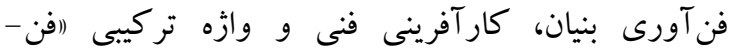
كار آفرينى" و نيز وازه ("فن آفرينى). كار آفرينى فن آورانه دو رســالت عمده را دزبال مى كند: نخست آنكه قصـد دارد با سـرعت بخشسيدن به روند تبديل علوم و دانش جديد به فن آورى، بتواند نياز هاى جامعه را

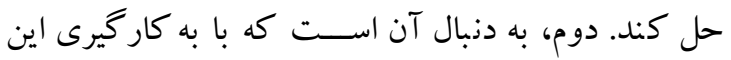

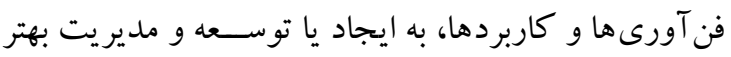

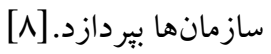
رشد شتابان صنعت توريسم درمانى و كار آفرينى در جهان، جندى نيست كه باعث تحول عظيم دررويدادهاى اقتصادى و افز ايش شكاف و فاصله بين كشورها شده است ونداشتن برنامهريزى اجرايى صسحيح در صـنعت توريسمم درمانى اين

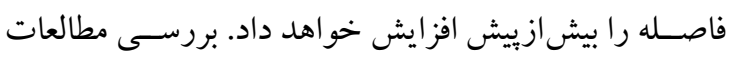

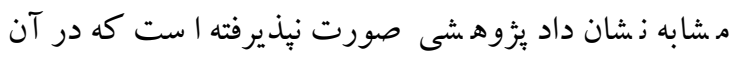
عوامل مؤثر بر توريسم درمانى از منظر كار آفرينى فن آورانه

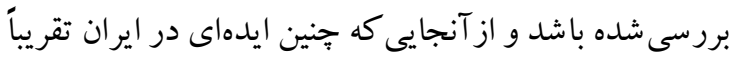
نو تلقى مى شود، به نظر مىرسد تهيه طرحى كه به اين مسئله

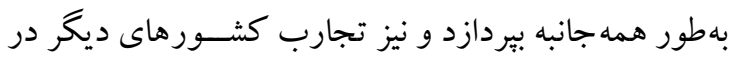

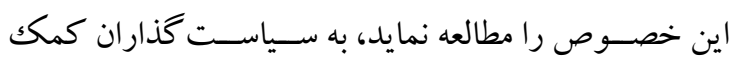

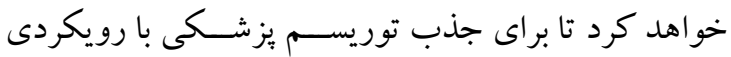
علمى و بومى حركت نمايند. با توجه به در آمد بالاى حاصل از توريســم درمانى در جهان واندك بودن سـهم ايران از صـنعت توريسـم درمانى وباتوجه به كار آفرينى و اشـتغال و در آمد ســــــار اين صـنعت هدف ثُزوهش حاضـر تعيين

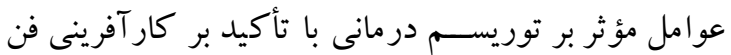

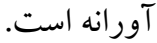

\section{روشها}

مطالعه حاضـر ازلحاظ هدف، كاربردى-توسعه اى از حيث روش اجرا كمى -دلفى و از نوع همبستخى ا ست. در مرحله اول براى شــاسـايى شـاخص هاى توريسـم درمانى مبتنى بر

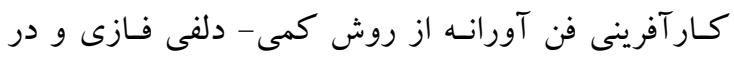

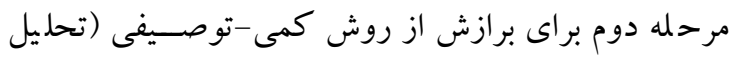
عاملى و براى رتبهبندى از روش سلسله مر اتبى) استفاده شده 
كمى - دلفى فازى و برخوردارى ازنظر خبر گان شاخصهاى كار آفرينى فن آورانه شنا سايى و با ا ستفاده از تحليل عاملى تأييدى به ترتيب به شش دسته كلى (تعاملات بين سازمانى -

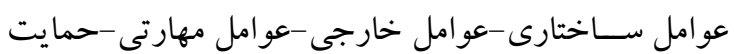

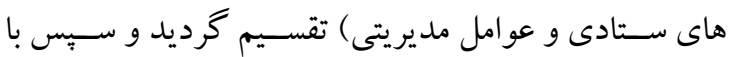

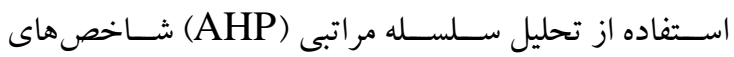

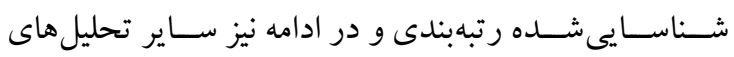

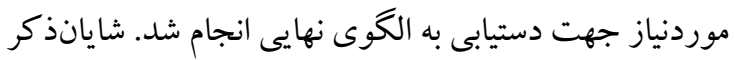

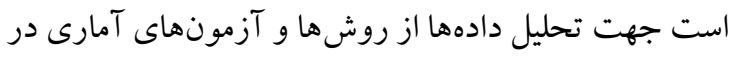
دو روش توصـيفى و اسـتنباطى نظير آزمون t تكك متغيره،

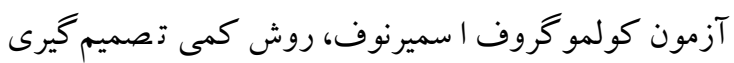

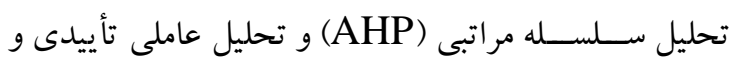

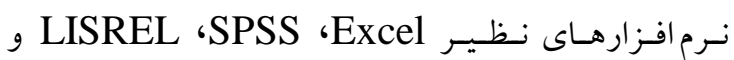
Expert Choice روش AHP كه در يزوهش حاضر از آن استفادهده جهت بريايى يك ساختار و قالب ردهاى براى مسئله، برقرارى ترجيحات از طريق مقايسات زوجى، برقرارى ساز كارى

منطقى از اندازه گيرىها است. [11

\section{يافته ها}

يُزوهش حاضر در دو مرحله مستقل انجام شد. هدف مرحله

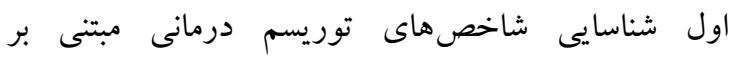

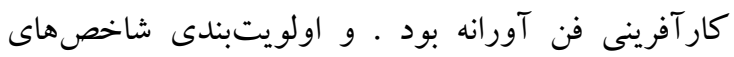

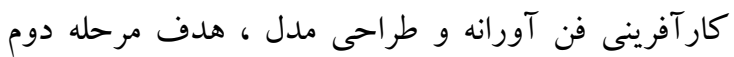

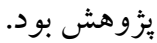

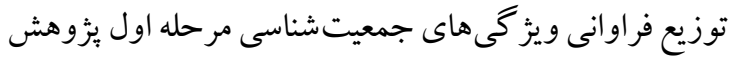

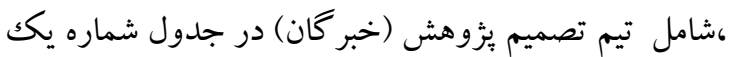

نشان دادهشده است.

بر اساس جدول شماره يك، بيشترين فراوانى خبر كان مربوط به كروه زنان و بيشترين سطح تحصيلات كارشناسى ارشد

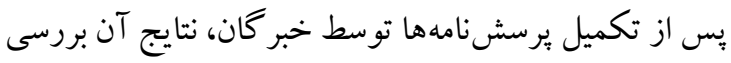
شد. بدين ترتيب كه مقادير به دست آمده متغيرها به مقادير
كزينه (اكاملاً موافقم)" تا گزينه (كاملاً مخالفم") بود. در مرحله نخسـت يس از تكميل يرسـشنامهها توسط خبر كان، نتايج آن بررسى شد. بدين ترتيب كه مقاديربه دست آمده متغيرها

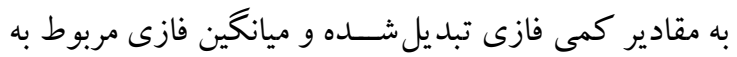
هر معيار به طور جداكانه تعيين و مقادير آن فازى زدايى نهي شـــند. براى شــاسـايى مؤلفههاى كار آفرينى فن آورانه از ماز روش كمى -دلفى فازى استفاده شد.

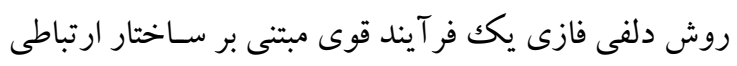

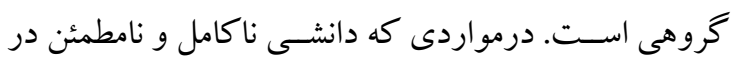

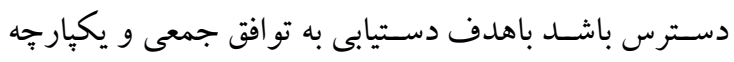

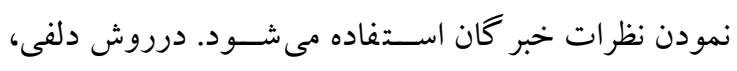
نظرات خبر كـان در قـالـب اعـداد قطعى بيـان مى شـــود، درحالى كه افراد خبره از شايستخى هاى ذهنى خود براى بيان

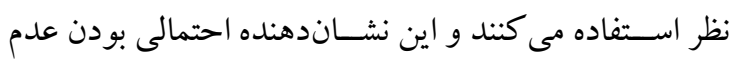
قطعيت حاكم براين شرايط است. احتمالى بودن عدم قطعيت

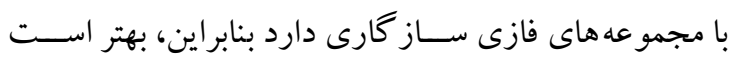

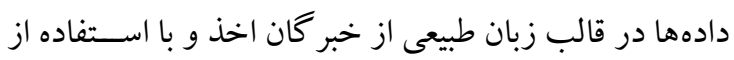

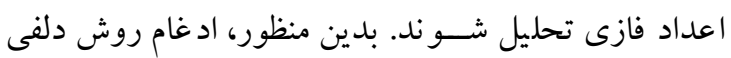
سنتى با تئورى فازى تحت عنوان روش دلفى فازى ارائه شده

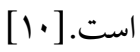

درمر حله دوم يُزوهش، يُرسـش نامه طراحى شـــه توسـط

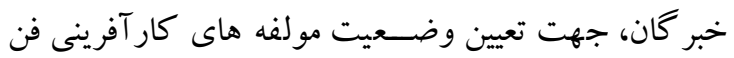
آورانه دراختيار جامعه آمارى كه شامل، كار شنا سان مراكز

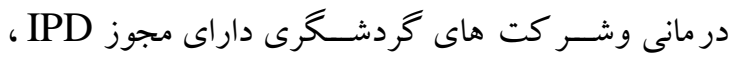
قرار گرفت. در يثزوهش حاضـر از يرسـش نامه با موضسوعات شــناسـايى مؤلفه هاى كار آفرينى فن آورانه با ون كو يه و اولويتبندى

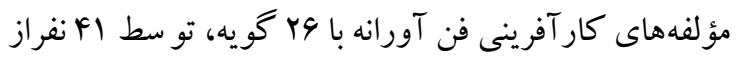

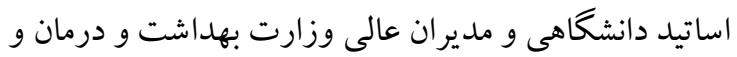

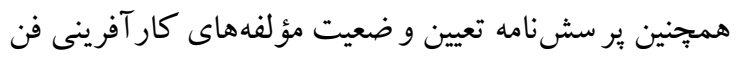

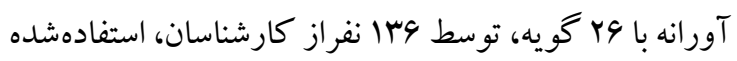

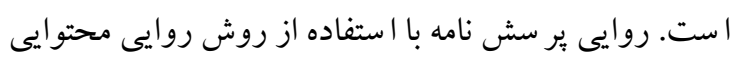

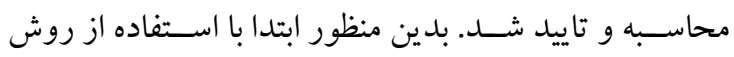


براى اطمينان از اينكه بتوان داده هاى موجود را براى تحليل استفاده كرد از تحليل عاملى استفاده شد؛ و از طريق محاسبه

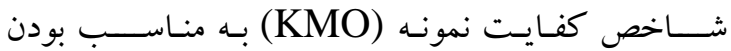
همبسـتكى هاى موجود در بين دادهها براى تحليل عاملى و با لها اسـتفاده از آزمون بارتلت از كفايت نمو نه كيرى اطمينان حاصل گرديد. با توجه به عدد KMO (بزر گك تر از V/•) و

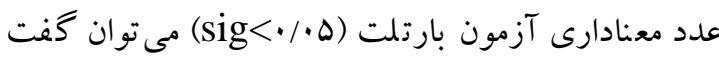
كه دادهها براى اجر اى تحليل عاملى مناسـبـ و از شـــايط

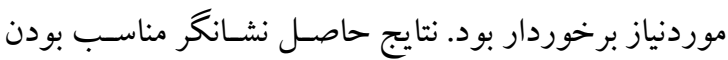

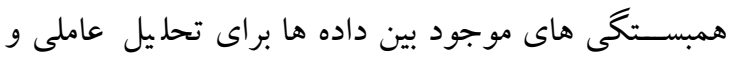

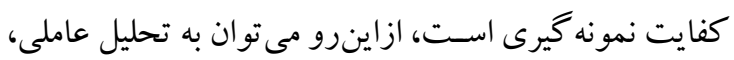

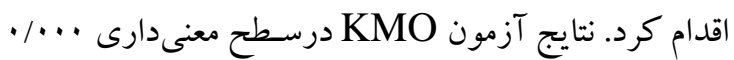
تائيد مى گردد.

براى برر سى منا سب بودن تمامى سؤالات در فر آيند تحليل عاملى از روش استخر اج، تحليل مؤلفه اصلى استفاده شـــ. جدول اشتراكات اوليه داراى دو ستون اوليه و اشتراكك است كه نشــان دهنده اشـتراكك يكك متغير (كو يه) برابر با مربع همبسـتخى جند گَانه (

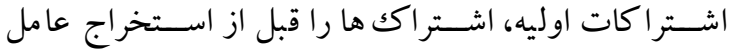
(عامل ها) بيان مى كند و تمامى اشـتر اككهاى اوليه برابر يكك

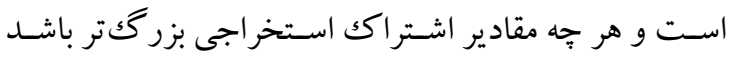

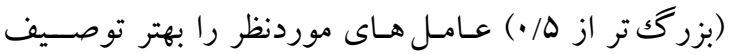

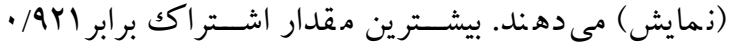

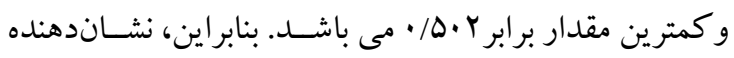
منا سب بودن تمامى سؤ الات در فر آيند تحليل عاملى بود. به علت اينكه عدد اشتراكات سؤالات از ه/· بيشتر بود. كل واريانس تبيين شده زشان مىدهد كه اين سؤالات شش عامل را تشـكيل مىدهند و اين عامل ها در حدود VFVV درصـــــ وار يانس را تبيين و بوشــش مى نما يد. بيشــترين

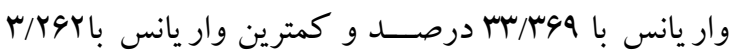
درصد مىباشد كه درواقع نشاندهنده روايى مناسب سؤالات

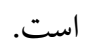
ماتريس جرخش يافته عاملى نشان مىدهد كه اين ماتريس

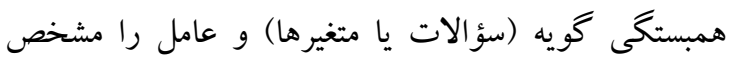

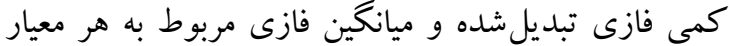
بهور جداكانه تعيين شد. سبس ميانخين فازى نظرات كليه خبر كان در مورد هر معيار بهدستآمده و مقادير آن فازى

$$
\text { زدايى شدند. (جدول دو) }
$$

\section{جدول (1): اطلاعات جمعيتشناسى خبر كان}

\begin{tabular}{|c|c|c|c|}
\hline فراوانى & فراوانى & \multicolumn{2}{|c|}{ متغير ها } \\
\hline rᄉ & 11 & مرد & جنس \\
\hline Tr & $r$ & زن & \\
\hline $1 \ldots$ & i) & جمع (جم & \\
\hline rT & ir & كارشناسى & ميزان تحصيلات \\
\hline$\varepsilon q$ & $r$. & كارشناسى ارشد & \\
\hline 19 & $\wedge$ & دكترى & \\
\hline $1 \cdots$ & il & جمع (جم & \\
\hline
\end{tabular}

با بررسى نتايج دور اول نظر سنجى، ميانخين هاى فازى زدايى

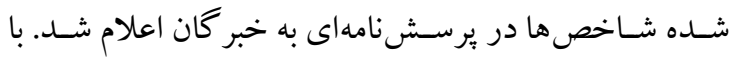

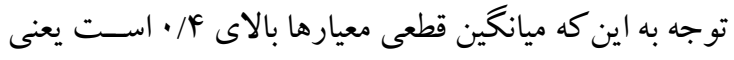

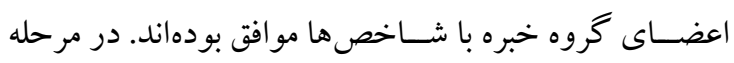

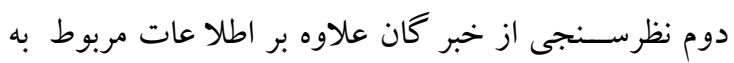

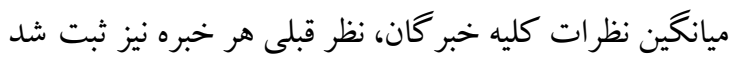

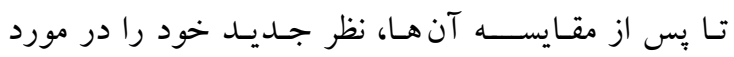

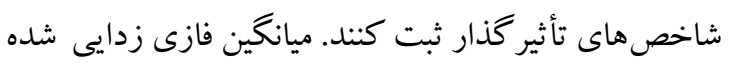
دور دوم نظر سنجى از خبر كان در جدول شماره سه آورده

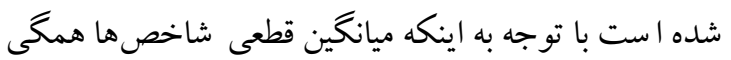
بالاى \&/ • مى باشــند؛ بنابر اين، اعضــاى گرووه خبره با تمام

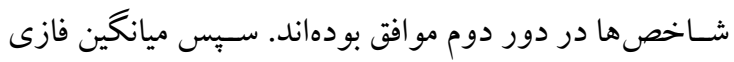

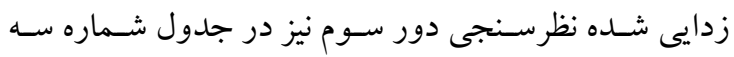

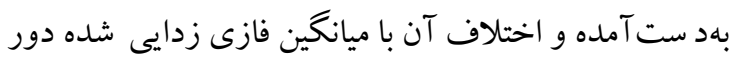
دوم نظر سنجى تعيين گرديد. با توجه به ديد گاههاى ارائه شده

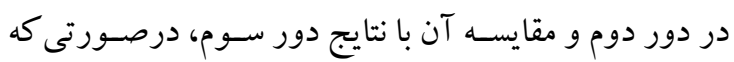

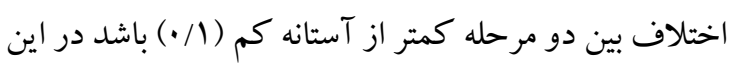

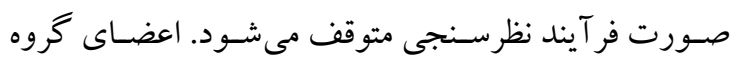

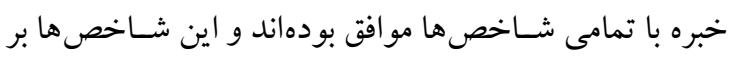
اساس روش دلفى فازى تائيد شدند. 


\section{نجارى و همكاران}

باشد عامل مربوطه نقش بيشترى در كل تغييرات (واريانس)

مى كند كه بر اساس ميزان همبستخى اين ارتباط روشن

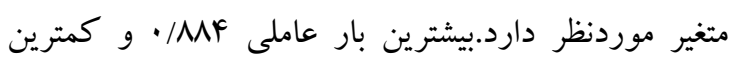

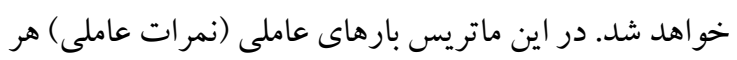

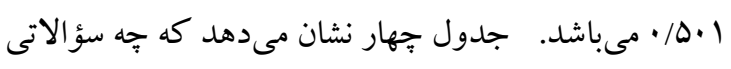

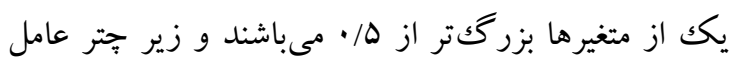
به اين عامل ها مر تبط هستند.

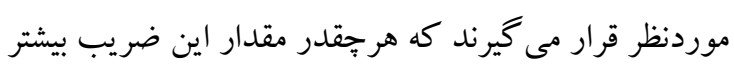

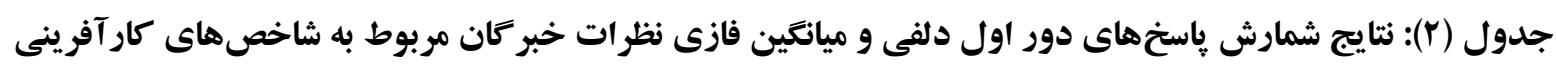
فن آورانه

\begin{tabular}{|c|c|c|c|c|c|c|c|c|}
\hline فازى زدايى شدين & ميانكين فازى & 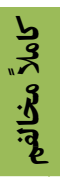 & & : & & 党 & شاخصهاى كار آفرينى فن آورانه & 3 \\
\hline .190 & $(\cdot / \cdot ، \cdot / \cdot \cdot 1)$ & . & r & $\wedge$ & ir & 11 & تعامل با جامعه در خصوص كار آفرينى فن آورانه & 1 \\
\hline .199 & $(\cdot / \cdot ، / A r, 1)$ & . & r & 9 & ir & iv & ارتباط و تعامل مديران بانكك با اساتيد دانشگاه بهويزٌه متخصصين كار آفرينى فن آورانه & $r$ \\
\hline .190 & $(\cdot / \cdot ، \cdot / \wedge \cdot ، 1)$ & . & $r$ & F & ir & rr & تعامل با بنكاههاى اقتصادى بهمنظور عملياتى كردن كسبو كارهاى فن آورانه & $r$ \\
\hline$\cdot / \mathrm{vA}$ & $\left(\cdot / \Gamma_{6} \cdot / 9 \cdot 6\right)$ & r & r & 4 & 11 & 19 & تعامل با بانككها براى استفاده از خدمات حاصل از كسبو كارهاى فن آورانه & $\varepsilon$ \\
\hline . NA & $(\cdot / \Gamma \cdot \cdot / 91,1)$ & . & r & $\Delta$ & ir & r. & تدوين و حمايت از دستور العمل هاى مرتبط با كار آفرينى فن آورانه در صنعت & 0 \\
\hline.$/ 91$ & $\left(\cdot / V_{6} \cdot / 9961\right)$ & r & r & $\wedge$ & 1. & in & تحقيق و توسعه كار آفرينى & 7 \\
\hline$\cdot / \mathrm{WV}$ & $\left(\cdot / \Gamma_{6} \cdot / 9 \cdot 61\right)$ & 1 & $r$ & $\Delta$ & ir & 19 & يل كار كنان بر فعاليت در حوزه كار آفرينى فن آورانه & $r$ \\
\hline$\cdot / 9$. & $\left(\cdot / N_{6} \cdot / 9 \Delta, 1\right)$ & . & r & 4 & ir & r. & فرهنك ازمانى & $\wedge$ \\
\hline$\cdot / \wedge 9$ & $\left(\cdot / V_{6} \cdot / 94,1\right)$ & 1 & r & 9 & 9 & rr & 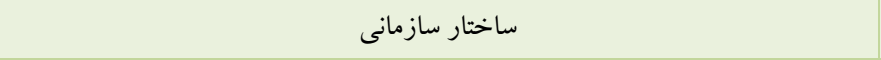 & 9 \\
\hline$\cdot / \mathrm{Na}$ & $($ ، (1) & 1 & r & 9 & ir & 19 & نو آورى سازمانى & $1 \cdot$ \\
\hline $.19 \mathrm{~V}$ & (،1) & 1 & 1 & v & ir & 19 & وزارت اقتصاد و دارايى از كار آفرينى فن آورانه & 11 \\
\hline$\cdot / \mathrm{WV}$ & $\left(\cdot / \Gamma_{6} \cdot / M, 1\right)$ & 1 & r & 4 & ir & 19 & تضمين امنيت و ريسك سرمايه كذارى در كار آفرينى فن آورانه & ir \\
\hline$\cdot / \mathrm{W}$ & $(\cdot / \wedge 9,1)$ & r & r & $\checkmark$ & 10 & 10 & نه بر توسعه كار آفرينى فن آورانه در صنعت بانكدارى & ir \\
\hline$\cdot 19 \mathrm{~V}$ & $(\cdot / \cdot ، / \wedge \Delta, 1)$ & 1 & r & F & ir & r) & قوانين و مقررات & $1 \varepsilon$ \\
\hline .191 & $(\cdot / \cdot ، / 149,1)$ & 1 & 1 & 1. & if & 10 & آموزش هاى ارائهشده متناسب با تقويت ايده يردازى و مهارتهاى كار آفرينى & 10 \\
\hline $.19 \mathrm{~V}$ & $(\cdot / \cdot ، / \wedge \Delta, 1)$ & · & 1 & $\checkmark$ & ir & r) & حمايت از كار كنان در اجراى بهموقع و سريع كار آفرينى فن آورانه & 17 \\
\hline $.19 \mathrm{~V}$ & $\left(\cdot / \cdot \cdot / A A_{6}(1)\right.$ & . & r & $\wedge$ & ir & iv & جهتدهى به رسانها در خصوص ترويج كار آفرينى فن آورانه در صنعت بانكدارى & iv \\
\hline . NG & $(\cdot / M, 1)$ & . & 1 & $r$ & iv & r. & رويكرد وزارت اقتصاد و دارايى در خصوص ترويج كار آفرينى فن آورانه در صنعت & 11 \\
\hline$\cdot / \mathrm{Na}$ & $\left(\cdot / \Gamma_{6} \cdot / 94,1\right)$ & . & r & $v$ & ir & 19 & ارائه خدمات به خوشههاى كار آفرينى فن آورانه & 19 \\
\hline$\cdot / \mathrm{Va}$ & $\left(\cdot / \Gamma_{6} \cdot / 9 r, 1\right)$ & 1 & r & $\wedge$ & 11 & 19 & انخيزه و تمايل مديران بر فعاليت در حوزه كار آفرينى فن آورانه & r. \\
\hline$\cdot / \mathrm{Va}$ & $\left(\cdot / \Gamma_{6} \cdot / 9 r_{6} 1\right)$ & 1 & r & $\checkmark$ & $\wedge$ & rr & توجه به يتانسيل هاى رشتههاى مختلف براى استقرار كار آفرينى فن آورانه & rI \\
\hline .191 & $(\cdot / \cdot \sqrt{ } \cdot \wedge 9,1)$ & . & r & $\Delta$ & ir & r & ميزان بذيذش مخاطرات ورود به فعاليت در حوزه كار آفرينى فن آورانه & rr \\
\hline$\cdot 191$ & $(\cdot / \cdot ، \cdot / \mathrm{AV}, 1)$ & . & r & $v$ & 1. & ry & مهارتهاى كار آفرينى مديران در ايجاد شبكه براى كسبو كارهاى فن آورانه & rr \\
\hline$\cdot 191$ & $(\cdot / \cdot 6 \cdot / \wedge \Delta, 1)$ & · & r & $\Delta$ & ir & r) & ييشينه ذهنى و اطلاعاتى مديران براى توسعه كار آفرينى فن آورانه & $r \varepsilon$ \\
\hline$\cdot / \mathrm{VA}$ & $(\cdot / \Gamma 6 / 9161)$ & & r & 9 & 9 & rr & مهارتهاى كار آفرينى در مديران در شناسايى و مديريت ريسكك كسبو كارهاى فن & ro \\
\hline$\cdot / \wedge \cdot$ & $\left(\cdot / \Gamma_{6} \cdot / 94,1\right)$ & r & r & 4 & 9 & rr & هوشيارى مديران بر فعاليت در حوزه كار آفرينى فن آورانه & r \\
\hline
\end{tabular}




\begin{tabular}{|c|c|c|c|c|}
\hline اختلاف & زمانكين فازى شده & زمانكين فازى شده & شاخصهاى كار آفرينى فن آورانه & 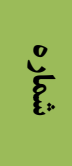 \\
\hline$\cdot / \cdot$ & $\cdot / 9$ & $\cdot / 9$ & تعامل با جامعه در خصوص كار آفرينى فن آورانه & 1 \\
\hline$\cdot / \cdot$ & $\cdot / \wedge 9$ & $\cdot / 19$ & ارتباط و تعامل مديران بانكك با اساتيد دانشگاه بهويزه متخصصين كار آفرينى فن آورانه & r \\
\hline.$/ .9$ & $\cdot / 19$ & $\cdot / \wedge \cdot$ & تعامل با بنكاههاى اقتصادى بهمنظور عملياتى كردن كسبو كارهاى فن آورانه & $r$ \\
\hline$\cdot / \cdot$ & $\cdot / \mathrm{V} \Lambda$ & $\cdot / \mathrm{V} \Lambda$ & تعامل با بانككها براى استفاده از خدمات حاصل از كسبو كارهاى فن آورانه & $\varepsilon$ \\
\hline$\cdot / \cdot$ & $\cdot / 9$ & $\cdot / 9$ & تدوين و حمايت از دستور العمل هاى مرتبط با كار آفرينى فن آورانه در صنعت بانكدارى & 0 \\
\hline$\cdot / \cdot 1$ & $\cdot / \mathrm{W}$ & $\cdot / \mathrm{V} \Lambda$ & تحقيق و توسعه كار آفرينى & 7 \\
\hline$\cdot / \cdot \wedge$ & $\cdot / \mathrm{AV}$ & $\cdot / \mathrm{V} 9$ & انخيزه و تمايل كار كنان بر فعاليت در حوزه كار آفرينى فن آورانه & $\checkmark$ \\
\hline$\cdot / \cdot$ & $\cdot / 91$ & $\cdot / 91$ & فر هنگك سازمانى & $\wedge$ \\
\hline$\cdot / \cdot v$ & $\cdot / \Lambda$ & $\cdot / 9$ & 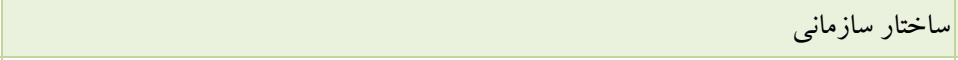 & 9 \\
\hline$\cdot / \cdot 1$ & $\cdot / \mathrm{V} 9$ & $\cdot / \mathrm{V} \Lambda$ & نو آورى سازمانى & $1 \cdot$ \\
\hline$\cdot / \cdot$ & $\cdot / 91$ & $\cdot / 91$ & حمايتهاى مادى و معنوى وزارت اقتصاد و دارايى از كار آفرينى فن آورانه & 11 \\
\hline$\cdot / \cdot$ & $\cdot / 91$ & $\cdot / 91$ & تضمين امنيت و ريسك سرمايه كذارى در كار آفرينى فن آورانه & ir \\
\hline$\cdot / \cdot$ & •/А9 & $\cdot / \wedge 9$ & آموزش مهارتهاى روانشناسانه بر توسعه كار آفرينى فن آورانه در صنعت بانكدارى & ir \\
\hline$\cdot / \cdot 1$ & $\cdot / A$. & $\cdot / \mathrm{Va}$ & 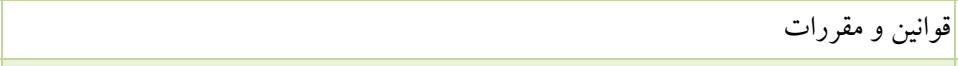 & $1 \varepsilon$ \\
\hline$\cdot / \cdot$ &.$/ 91$ & $\cdot / 91$ & آموزش هاى ارائهشده متناسب با تقويت ايده بردازى و مهارتهاى كار آفرينى & 10 \\
\hline$\cdot / \cdot 1$ & $\cdot / 91$ & $\cdot / 9 r$ & حمايت از كار كنان در اجراى بهموقع و سريع كار آفرينى فن آورانه & 17 \\
\hline$\cdot / \cdot 1$ & $\cdot / 9 \cdot$ & $\cdot / 91$ & جهتدهى به رسانها در خصوص ترويج كار آفرينى فن آورانه در صنعت بانكدارى & iv \\
\hline$\cdot / \cdot$ & $\cdot / 91$ & $\cdot / 91$ & رويكرد وزارت اقتصاد و دارايى در خصوص ترويج كار آفرينى فن آورانه در صنعت بانكدارى & 11 \\
\hline$\cdot / \cdot$ &.$/ 9$. &.$/ 9$ & ارائه خدمات به خوشههاى كار آفرينى فن آورانه & 19 \\
\hline$\cdot / \cdot r$ & $\cdot / M$ & $\cdot / 9$ & انخيزه و تمايل مديران بر فعاليت در حوزه كار آفرينى فن آورانه & $r \cdot$ \\
\hline$\cdot / \cdot \mathrm{F}$ & $\cdot / \wedge \Delta$ & $\cdot / 19$ & توجه به يتانسيل هاى رشتههاى مختلف براى استقرار كار آفرينى فن آورانه & rl \\
\hline .1 .9 & $\cdot / \wedge 9$ & $\cdot / \wedge \cdot$ & ميزان يذيرش مخاطرات ورود به فعاليت در حوزه كار آفرينى فن آورانه & rr \\
\hline$\cdot / \cdot r$ & $\cdot|\wedge|$ & $\cdot / \mathrm{V} \Lambda$ & مهارتهاى كار آفرينى مديران در ايجاد شبكه براى كسبو كارهاى فن آورانه & r \\
\hline$\cdot / \cdot$ & $\cdot / 9 \cdot$ & $\cdot / 9$ & "يشينه ذهنى و اطلاعاتى مديران براى توسعه كار آفرينى فن آورانه & $r \varepsilon$ \\
\hline$\cdot / \cdot 1$ & $\cdot / \mathrm{Va}$ & $\cdot / \mathrm{V} \Lambda$ & مهارتهاى كار آفرينى در مديران در شناسايى و مديريت ريسك كسبو كارهاى فن آورانه & ro \\
\hline$\cdot / \cdot r$ & $\cdot / \Lambda \mid$ & $\cdot / \sqrt{ } 9$ & هو شيارى مديران بر فعاليت در حوزه كار آفرينى فن آورانه & rq \\
\hline
\end{tabular}

ارشد وبيشترين فراوانى محل فعاليت بِاسخ دهند كان مربوط

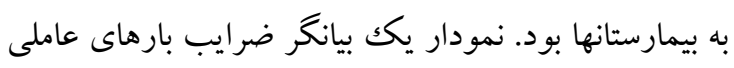

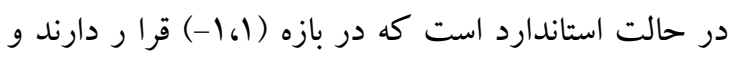
نشاندهنده ميزان رابطه بين متغيرها مىباشند. مقدار ملاكك

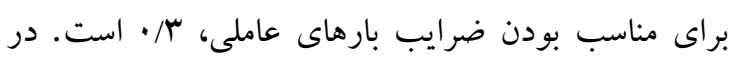

توزيع فراوانى ويزگ گهاى جمعيتشناسى مرحله دوم

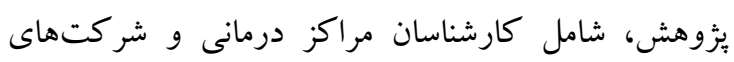
كردشخرى سلامت در جدول شماره ״نج نشان دادهشده

بر اساس جدول شماره بنج ، بيشترين فراوانى باسخ دهند گان

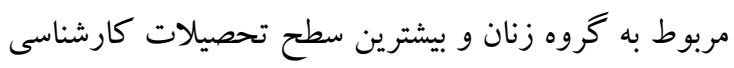


جدول (0): اطلاعات جمعيتشناسى پِاسخدهندكان

\begin{tabular}{|c|c|c|c|}
\hline فراونى & فراوانى & & \\
\hline rᄉ & $\Delta r$ & مرد ل مرد & \multirow{3}{*}{ جنس } \\
\hline$\pi$ & $\Delta F$ & زن & \\
\hline $1 .$. & $1+4$ & جمع ( جمع & \\
\hline rq & rq & كارشناسى & \multirow{4}{*}{ تحيلات } \\
\hline 00 & vo & كارشناسى ارشد & \\
\hline 17 & rr & دكترى & \\
\hline $1 .$. & 154 & جمع & \\
\hline rq & 1.4 & بيمارستان & \multirow{3}{*}{ محل فعاليت } \\
\hline$r \varepsilon$ & rr & شر شركتى سلامت & \\
\hline $1 .$. & 149 & جمع & \\
\hline
\end{tabular}

همانطور كه در نمودار شماره دو مشاهده مىشود، مقادير بزرگكتر از (T-value)

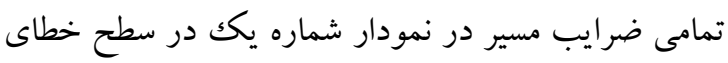

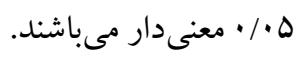

نمودار فوق تمامى اعداد ضرايب بارهاى عاملى سؤالات از r/ • بيشتر است كه نشان از مناسب بودن اين معيار دارد.

\section{جدول (ع): دستهبندى شاخصهاى كار آفرينى فن}

آورانه

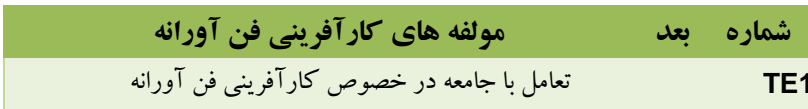

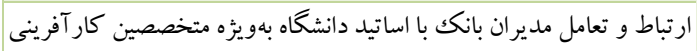
فن آورانه

تعامل با بنكاههاى اقتصادى بهمنظور عملياتى كردن كسبو كارهاى فن آورانه

تعامل با بانككها براى استفاده از خدمات حاصل از كسبو كارهاى فن آورانه

تدوين و حمايت از دستور العمل هاى مرتبط با كار آفرينى فن آورانه در صنعت بانكدارى تحقيق و توسعه كار آفرينى

انكيزه و تمايل كار كنان بر فعاليت در حوزه كار آفرينى فن آورانه TE7

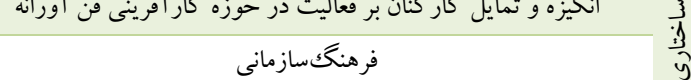
के TE8

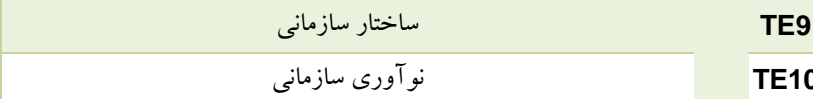

حمايتهاى مادى و معنوى وزارت اقتصاد و دارايى از كار آفرينى فن آورانه TE11

تضمين امنيت و ريسك سرمايه كذارى در كار آفرينى فن آورانه y TE12

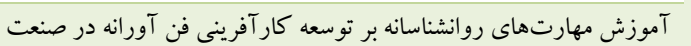
بانكدارى

$$
\text { قو انين و مقررات }
$$

TE14

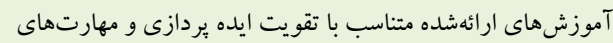

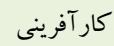

TE15

حمايت از كار كنان در اجراى بهموقع و سريع كار آفرينى فن آورانه

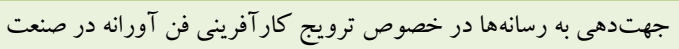
بانكدارى

رويكرد وزارت اقتصاد و دارايى در خصوص ترويج كار آفرينى فن آورانه در صنعت بانكدارى

TE18

\begin{tabular}{|c|c|c|}
\hline ارائه خدمات به خوشههاى كار آفرينى فن آورانه & 1 & TE1 \\
\hline انخيزه و تمايل مديران بر فعاليت در حوزه كار آفرينى فن آورانه & & TE2 \\
\hline توجه به يتانسيل هاى رشتهاى مختلف براى استقر ار كار آفرينى فن آورانه & 3 & TE2 \\
\hline ميزان يذيرش مخاطرات ورود به فعاليت در حوزه كار آفرينى فن آورانه & $\hat{y}$ & TE2 \\
\hline مهارتهاى كار آفرينى مديران در ايجاد شبكه براى كسبو كارهاى فن & & \\
\hline يِيشينه ذهنى و اطلاعاتى مديران براى توسعه كار آفرينى فن آورانه & $\overline{3}$ & \\
\hline مهارتهاى كار آفرينى در مديران در شناسايى و مديريت ريسك كارهاى فن آورانه & 3 & TE2 \\
\hline
\end{tabular}




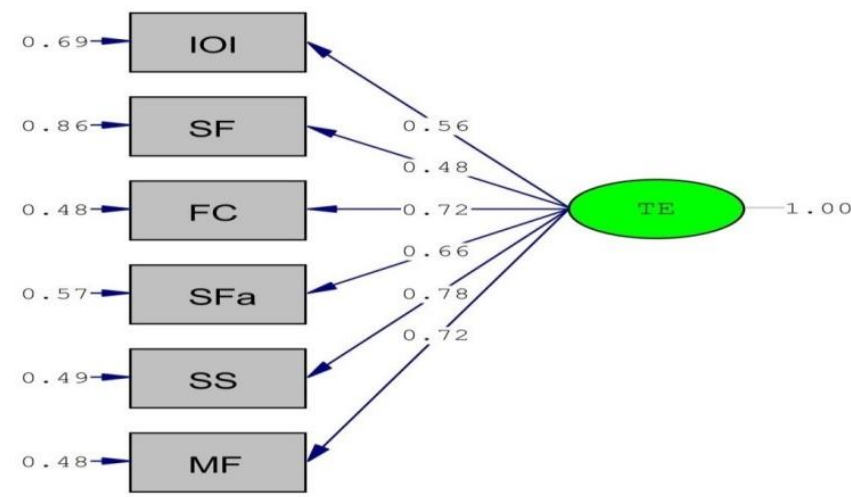

Chi-Square=14.81, $d f=9, \quad P-v a l u e=0.0000$, RMSEA=0.056

نمودار ( ): نتايج تحليل عاملى تائيدى شاخص كار آفرينى فن آورانه بر اساس ضرايب استانداردشده

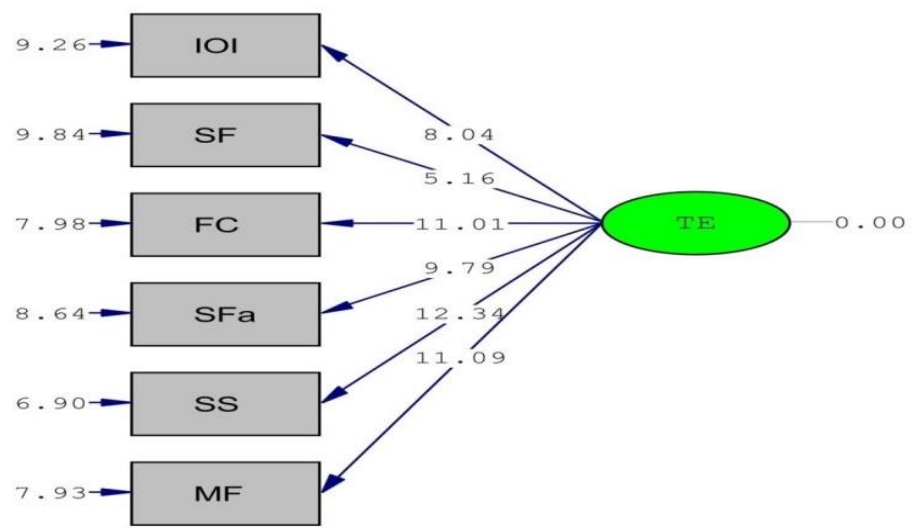

Chi-Square=14.81, $d f=9, \quad P-v a l u e=0.0000$, RMSEA=0.056

نمودار (Y): نتايج تحليل عاملى تائيدى شاخص كار آفرينى فن آورانه بر اساس ضرايب معنادارى

با توجه به نتايج حاصل از نرمافزار

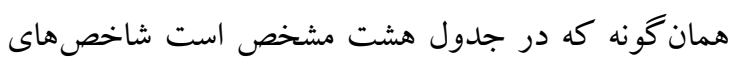

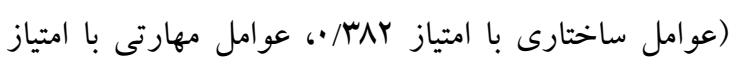

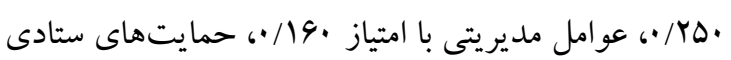

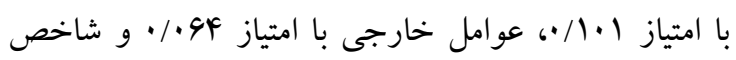

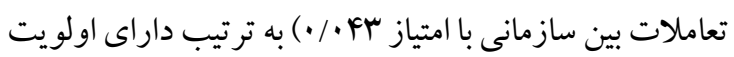

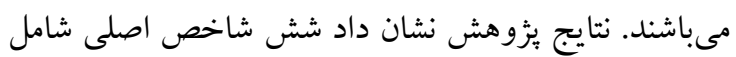
عوامل ساختارى، مهارتى، مديريتى، حمايتهاى ستادى،

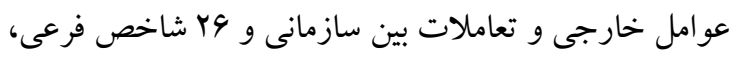
بهاعنوان مهمترين شاخص هاى توريسم درمانى مبتى بر كار آفرينى فن آورانه معرفىشده است. (شكل يكك)
دو شاخص مهم برازش مدل (RMSEA) و (CMIN/DFx /df) (CMIN/DFx $\left.{ }^{2} / \mathrm{df}\right)$ هر جָه كوجگكتر از عدد سه باشد (CMIN/DFx² /df) مدل دار اى برازش بهترى است. شاخص RMSEA ميانگين مجذور خطاهاى مدل است كه برابر هه×/• برآورد شده است. اين شاخص بر اساس خطاهاى مدل ساخته مى شود حد

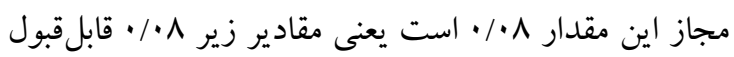

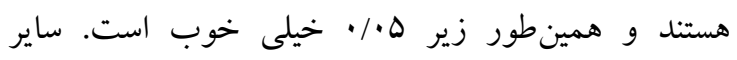

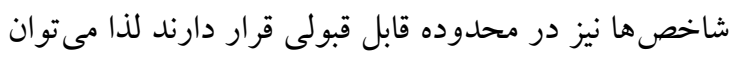
كفت مدل از برازش مناسبى برخوردار است. [Y 
جدول (7): نتايج حاصل از بررسى نيكويى برازش مدل ساختارى شاخص كار آفرينى فن آورانه

\begin{tabular}{|c|c|c|c|c|c|c|c|c|}
\hline IFI & NNFI & NFI & AGFI & GFI & RMSEA & SRMR & CMIN/DF & شاخص برازندىى \\
\hline$>\cdot, 9$ & $>\cdot, 9$ & $>\cdot, 9$ & $>\cdot, 9$ & $>\cdot, 9$ & $<\cdot, \cdot \wedge$ & $<\cdot, \cdot \Delta$ & $<r$ & مقادير قابلقبول \\
\hline.$/ 97$ & .190 &.$/ 97$ &.$/ 94$ & $\cdot / 9 \varepsilon$ & .1 .07 & $\cdot / \cdots$ & $1 / 70$ & مقادير محاسبهشده \\
\hline
\end{tabular}

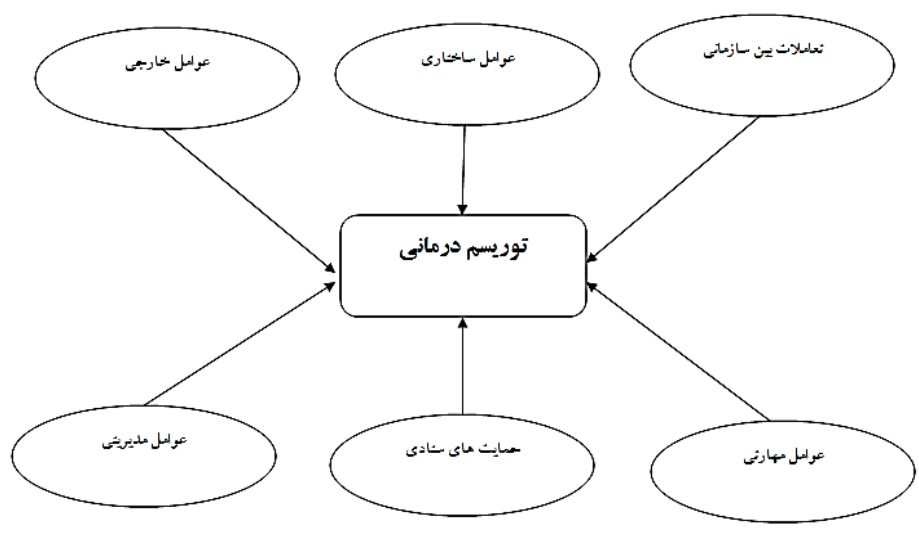

شكل (1): مدل مفهومى نهايى ثزوهش

\section{بحث}

در مطالعه حاضر، عوامل مؤثر بر توريسم درمانى با تأكيد بر كار آفرينى فن آورانه در ايران بررسى شد. نتايج بهدست آمده

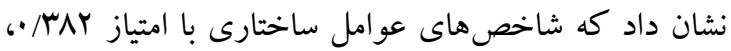

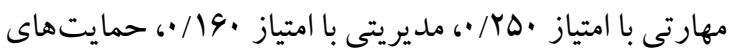

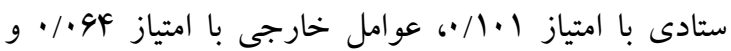

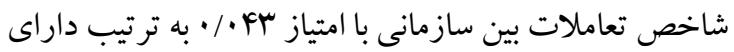

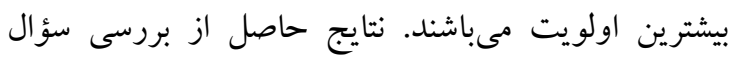
يثزوهش نشان مىدهد كه استفاده از شاخصهاى شناسايىشده در متغير كار آفرينى فن آورانه در رشدو و توسعه

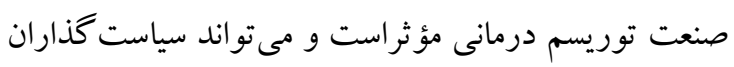
و مديران اين صنعت را يارى نمايد.

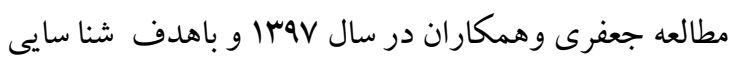

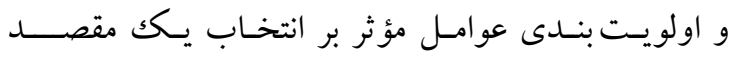

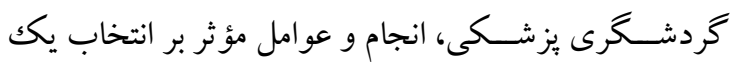

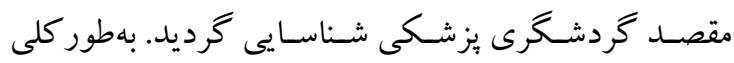

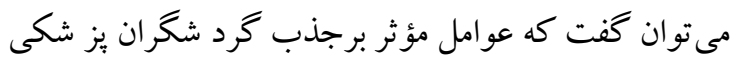
به ترتيب اهميت شـامل جهار بعد فن آورى درمان، كار كنان
جدول (Y): اختصار شاخصهاى برازش

\begin{tabular}{|c|c|c|}
\hline نام شاخص & شاخصها & اختصار \\
\hline سطح تحت يوشش گاى دو & \multirow{3}{*}{ شاخص هاىبر ازش - } & Chi-Square \\
\hline شاخصنيكويىبرازش & & GFI \\
\hline شاخصنيكويىبرازش تعديل & & AGFI \\
\hline شاخصبرازشهنجارنشده & \multirow{5}{*}{ شاخصهاىبرازش - تطيقى } & NNFI \\
\hline شاخص برازش هنجارشده & & NFI \\
\hline شاخصبرازشتطبيقى & & CFI \\
\hline شاخصبر ازشنسبى & & RFI \\
\hline شاخصبر ازشفراينده & & IFI \\
\hline مقتصدهنجارشده - ماخد & \multirow{3}{*}{ ماخصهاىبرازش - مقتصد } & PNFI \\
\hline ريشهميانكين مربعات خطاى- & & RMSEA \\
\hline كاىمربعبهنجارشده & & CMIN \\
\hline
\end{tabular}

جدول (^): امتياز و رتبه شاخصهاى كار آفرينى فن آورانه

\begin{tabular}{|c|c|c|}
\hline 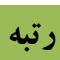 & امتياز & شاخص \\
\hline 1 & 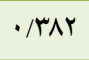 & عوامل ساختارى (SF) \\
\hline r & . /YA & عوامل مهارتى (SFa) \\
\hline$r$ &.$/ 19$ & عوامل مديريتى (MF) \\
\hline$r$ &.$/ 1 \cdot 1$ & حمايتهاى ستادى (SS) \\
\hline$\Delta$ & .1 .94 & عوامل خارجى (FC) \\
\hline 4 &.$/ . k r$ & تعاملات بين سازمانى (IOI) \\
\hline
\end{tabular}


صاحبنظران، كار آفرينى فن آورانه كليد توسعه فن آورى و اقتصاد است.[19] مطالعه كرمى وهمكاران در سال هوسا و باهدف شنا سايى و

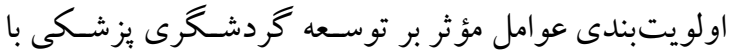
تأكيد بر گردشخر ان داخلى (نمونه موردمطالعه: شهر مشهد)،

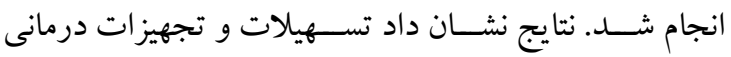

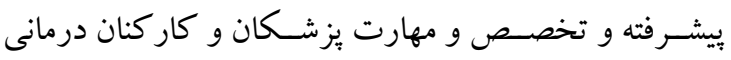

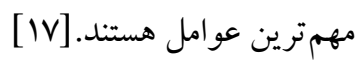

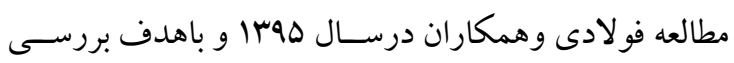

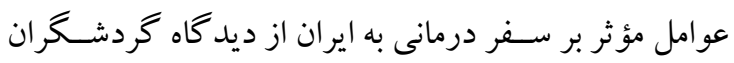

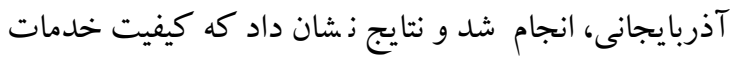

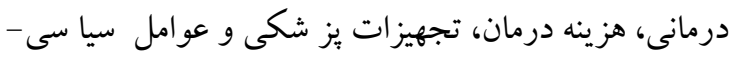

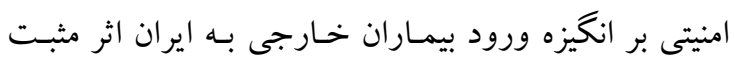

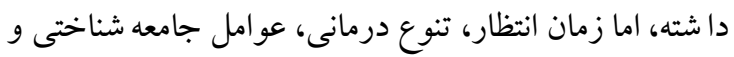
جاذبه هاى گردشخرى، تأثير زيادى نداشتند. [11]

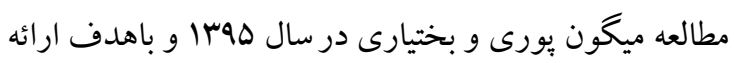
الكوى نظرى عوامل مؤثر بر فر آيند كار آفرينى فن آورانه سازمانى در شر كتهاى فعال در حوزه زيست فن آورى سبز،

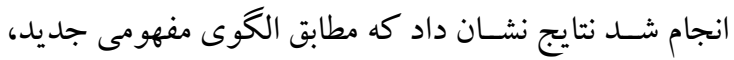

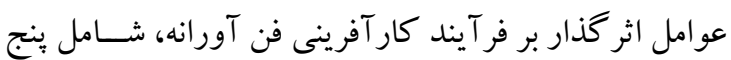

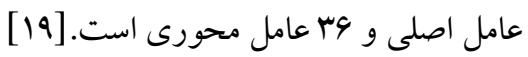
بديعى و همكاران در سال هوسا يزوهشى با عنوان شنا سايى ورتبه بندى راهكارهاى تو سعه گرد شخرى يز شكى؛ مطالعه

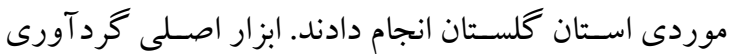
دادهها مصحاحبه و ير سشنامه است. يافتهاى بثزوهش زشان داد كه تأثير گذارترين معيارهاى اصلى در توسعه گردشكرى يز شكى ا ستان گلمستان به ترتيب اهميت، معيار زير ساختار،

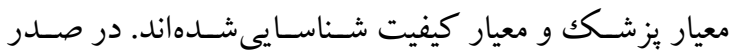
راهـكار هاى ارائه شـــــه در اين يثزوهش، بالا بردن ميزان هشاركت خصو صى در تو سعه گرد شخرى بز شكى استان

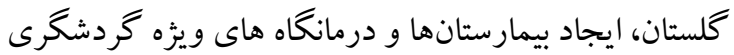

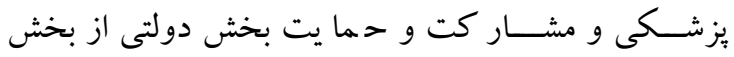

خصوصى را مى توان نام برد. [r.
تعيين عوامل مؤثر بر توريسه درمانى...

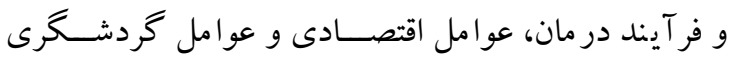

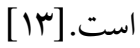
مطالعه عليدادى ســليمانى وز مانى درســال Vوسا باهدف شـناسـايى و اولويتبندى عوامل مؤثر برجذب گردشـــران

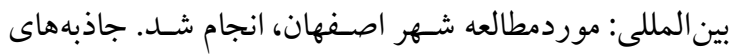

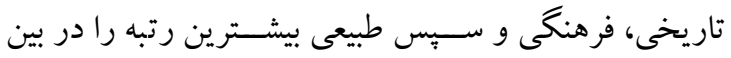

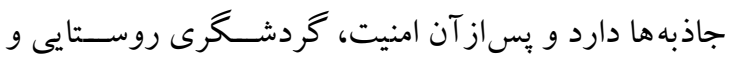

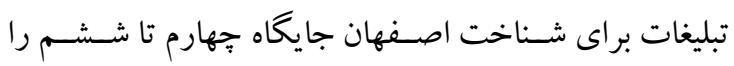
دارد، نرخ ارز، مذهب و زيرساختها در جايگاه هفتم تا نهم

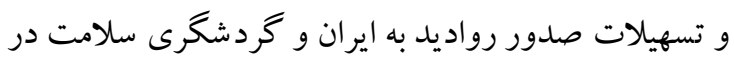
جايخاه دهم و يازدهم قرار دارد. [IF]

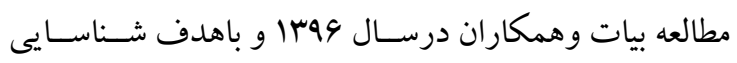
عو امل جذب گردشـخران يز شـكى در بيمارستانهاى شـهـر

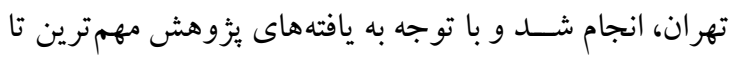

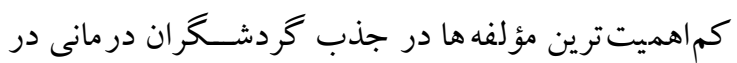

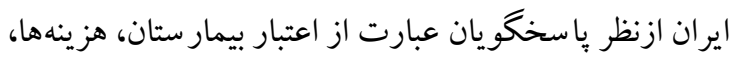

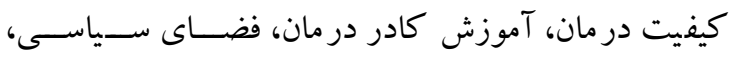
سـياسـتهاى نظارتى، زيرسـاختها و موقعيت بيمارسـتان و

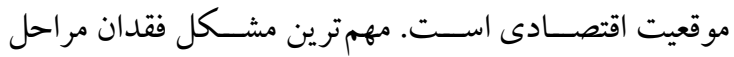
درمانى شفاف و سيستم حمايتى بيان شد. در مطالعات مشابه،

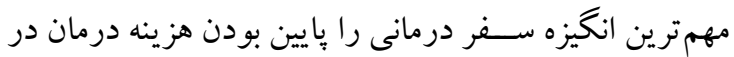
كثـور مقصـــ شــاسـايى كردهاند و براى تصـميم گيرى در خصوص مقصد نيز به شرايط سيا سى، اقتصادى، قوانين و

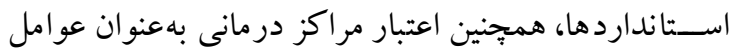
اثر كذار اشارهشده است.[10]

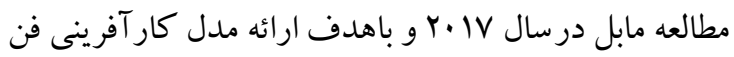
آورانه در شر كتهاى دانشبنيان مستقر در بار ككهاى علم و فن آورى: رويكرد كيفى در كثـور آلمان انجام شـد، روش دان

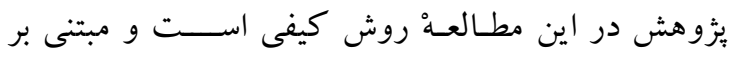
مصاحبههاى اكتشـافى و بر گزارى گروههاى كانونى بود كه

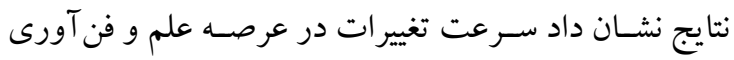
آنجنان زياد اسـت كه عدم اطمينان بارزترين ويز گیى محيط

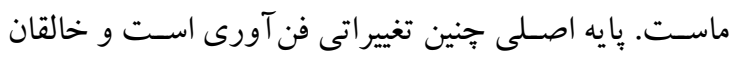

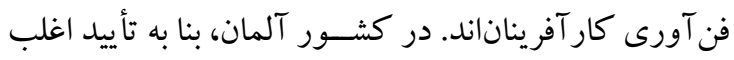


بر اساس يافتهاى يزوهش حاضر ييشنهادهايى شامل استفاده

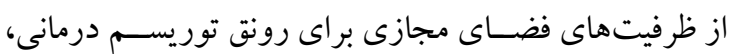
ايجاد ويزاى درمانى جهت بيمارانى كه براى درمان به كشور سفر مى كنند تا بتواند بدون طى تشريفات وارد كشور شوند، امكان دســر سـى شـبانهروزى متقاضـيان خدمت، از طريق

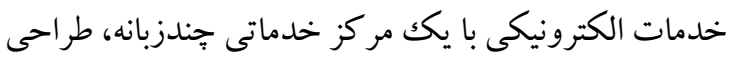
و تدوين راهكارهاى بذيرش بيمه تكميلى كشـــورهاى بازار هدف، برند سازى براى قطبهاى گرد شخرى كشور، آ شنا بـان

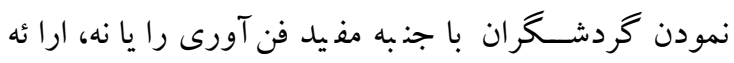

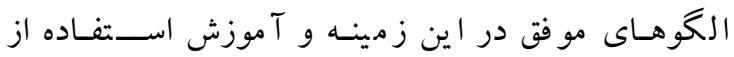
نرمافزار هاى تخصــصـى در زمينه توريســم درمانى ارائه مى شود.

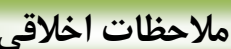

رعايت دستورالعملهاى اخلاقى: اين يزوهش با كد اخلاق به شماره IR.IAU.AK.REC.1398.015 اخذشده از كميته اخلاق در يزوهشهاى زيست يزشكى لهار

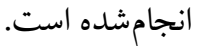
حمايت مالى: يزوهش حاضر از سوى هيج سازمانى

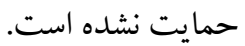
تضاد منافع: نويسند گان اظهار داشتند كه تضاد منافعى

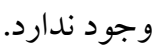
تشكر و قدردانى: اين مقاله حاصل بخشى از بايانامه با عنوان (اطراحى الكوى توريسم درمانى مبتنى بر كار آفرينى

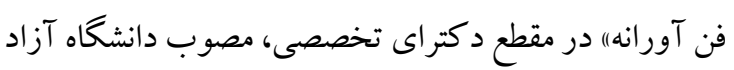

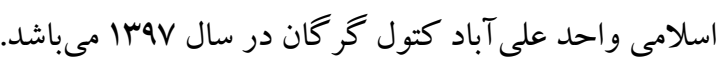

مطالعه نيككرفتار وهمكاران درسال Fqجا و باهدف شناسايى عوامل مؤثر در جذب گردشــر ان بزشـكلى در ايران انجام شد. ابزار اصلى گردآورى دادهها، بر سشنامه بوده و جامعه آمارى اين مطالعه شـامل كليه گردشــرانى بود كه در زمان

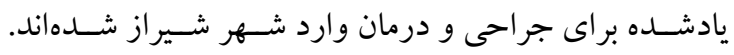

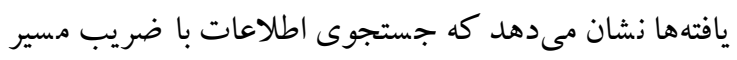
(4Y/•) اثر بسـيار مهمى در انتخاب ايران بهعنوان كشــور مقصد در گردشخرى سلامت دارد. عوامل محر كى تقاضا و تسهيل كننده كلان با ضرايب مسير به ترتيب ( الس/ • و r//.)

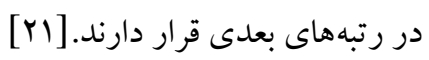

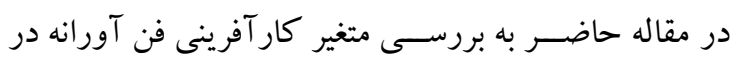
توريسم درمانى برداخته شد كه در يثزوهش هاى قبلى كمتر به

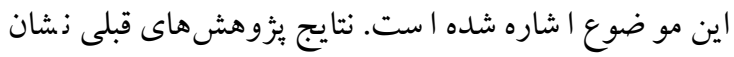

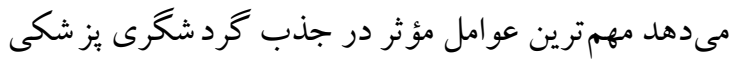

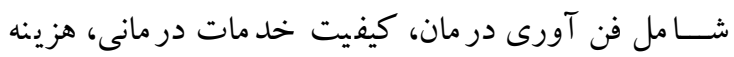
درمان، تجهيزات يُزشــكى اســـت در حالى كه تأكيد مقاله حاضـر بر كار آفرينى فن آورانه هســت .در تحقيق بيات

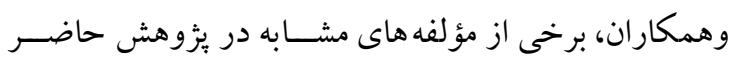

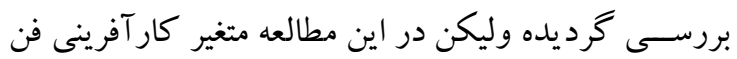

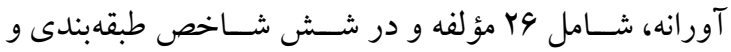
بررسـى گرديـده كـه در هُزوهش بيـات وهمكـاران جنين

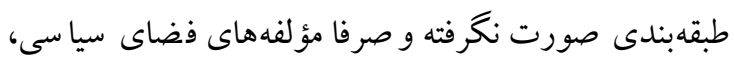
سـياسـتهاى نظارتى، سـيسـتم حمايتى، قوانين و مقررات،

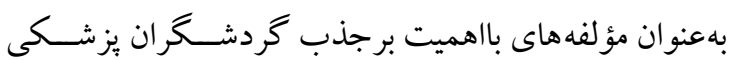

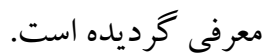




\section{References}

1. Health Tourism [Internet]. 2017[cited 2017 Jan 12]; Availabel from: www.markazi:tourist.ir. [In Persian]

2. Wall S. Hemingway A.Curtin S. Engaging with a healthy tourism "offer": strategies to improve place perception. Worldwide Hospitality and Tourism Themes. 2017; 9(5): 525-533.

3. Hosseini Nejad R. Daryabari G. Investigating the role of tourism in sustainable regional development (Case study: Health tourism in Ardabil province). Geography Quarterly (Regional Planning). 2018; (7)3: 55-63. [In Persian]

4. Rezaei N. Mirzaei F. Manshizadeh R. Assessing the position of tourism in the rural economy (Case study: Moridan Village, District of Komala, County of Langroud). Journal of Geographical Information (Sepehr).2018; 27 (108): 225-236. [In Persian]

5. Panahi H. Azizi M. Assessing the capability of Tabriz hospitals in developing health tourism. Journal of Health.2018; 9(1):100-114. [In Persian]

6. Padilla A. Cachanosky N. Indirectly Productive Entrepreneurship. Journal of Entrepreneurship and Public Policy. 2016; 5(2): 161-175.

7. Khalil S. O'sullivan P. Corporate Social Responsibility: Internet social and environmental reporting by banks. Meditari Accountancy Research. 2017; 25(3): 414-446.

8. Ghazipour R. Moghaddam R. Razavi H. The Impact of Information Technology on Organizational Entrepreneurship at Shahroud University [Master thesis]. Shahroud: Iran Shahroud Islamic Azad University; 2018. [In Persian]

9. Mehdizadeh Ashrafi A, Hosseini M, Research Method in Human Sciences. Tehran: Yekan; 2006. [In Persian]

10. Hafeznia M.R, An Introduction to the Research Method in Humanities(total revision with additions). 2nd ed. Tehran: samt; 2010. [In Persian]

11. Asgharpour M.J, Multiple Criteria Decision Making. Tehran: Tehran University; 1998. [In Persian]

12. Tabachnick BG, Fidell LS, Ullman JB. Using multivariate statistics. Boston, MA: Pearson; 2007 Mar 3.

13. Jafari M. Jandaghi Gh. Rafiee S.Identifying and prioritizing factors influencing the choice of a medical tourism destination. Health Information Management.2018; 15(2): 83-89. [In Persian]

14. Alidadi soleimani L, Zamani Z, editors. Identifying and prioritizing the factors affecting the attraction of international tourists (Case study: Isfahan City).Proceedings of the Conference on Civil Engineering. Architecture and Urban Planning of the Islamic World; 2018 May 10; Tabriz, Iran.Tabriz university ; 2018. [In Persian]

15. Bayat S. Hosseini Hashemzadeh D. Bad M. Attracting Factors Identification of Medical Tourists in Hospitals of Tehran City. Hospital Quarterly.2016; 16 (1):35-53. [In Persian] 
نجارى و همكاران

16. Mabel B. Concise Guide to Entrepreneurship. Technology and Innovation. Reference Reviews.2017; 31(3):15-15.

17. Karami F. Bayati M. Talebzadeh A.Identification and prioritization of effective factors for the development of medical tourism with emphasis on domestic tourists. Journal of Geography and Regional Development.2016; 14 (2):109-128. [In Persian]

18. Fouladi N. Habibzadeh Sh. Barari S. Ali Mohammadi Asl H. Homayounfar N. Nemati A. Factors affecting medical travel to Iran from the perspective of Azerbaijani tourists. Journal of Health and Care.2018; 20 (3): 252-260. [In Persian]

19. Migon Puri M, Bakhtiari H, editors. Presenting a theoretical model of factors affecting the process of organizational technological entrepreneurship in companies active in the field of green biotechnology. Proceedings of the First national conference on knowledge-based employment; 2017 Februrary 21-22; Sanandaj, Iran. Jihaddaneshgahi of Kurdistan Province ;2017.[In Persian]

20. Badiee F.Ebrahimi A.Didehkhani H. Identification and implementation of strategies for the development of medical tourism A case study of Golestan province. Journal of Modern Marketing Research.2016; 6(4):25-36. [In Persian]

21. Nikraftar T.Hosseini E. Moghadam A. Identify Factors Affecting Medical Tourism Attraction in Iran. Journal of Health Administration.2016; 20 (67): 64-74. [In Persian] 